Jurnal

Belo
Volume 6 Nomor 2 Februari 2021 - Juli 2021

DOI: https://doi.org/10.30598/belovol6issue2page157-178

p-ISSN : 2460-6820 | e-ISSN : 2686-5920

Penerbit : Fakultas Hukum Universitas Pattimura

\title{
Penerapan Asas Ultimium Remedium Pada Pelanggaran Pemilihan Umum Dalam Undang-Undang Nomor 7 Tahun
}

\section{7}

\section{Patrick Corputty ${ }^{1, *}$}

${ }^{1}$ Fakultas Hukum Pattimura, Ambon

corputtyp@gmail.com ${ }^{1}$

* Corespondence Author

\begin{abstract}
Abstrak
Pemilihan Umum Tahun 2019 adalah wujud dari Kekuasaan ditangan rakyat namun tidak bisa dipungkiri bahwa masih banyak terjadi pelanggaran pemilu baik bersifat pidana, administratif maupun kode etik, namun dalam prakteknya masih banyak rekomendasi Badan Pengawas Pemilu tidak dilaksanakan oleh Komisi Pemilihan Umum. Tujuan penulisan ini untuk menemukan pengunaan pidana sebagai upaya terakhir dalam proses pelangaran Pemilu. Metode yuridis normatif. Ultimium Remedium, penggunaan pidana sebagai upaya terakhir dalam proses penegakan hukum, sangat penting dalam proses Demokrasi di Indonesia, karena hukum pidana dipakai sebagai penjaga marwah hukum.
\end{abstract}

\section{Kata Kunci : Penerapan, Ultimium Remedium, Pemilihan Umum}

Naskah dikirim: 7 Januari 2021|Direvisi: 10 Febuari 2021|Diterbitkan: 28 Februari 2021

\section{Abstract}

The 2019 General Election is a form of power in the hands of the people, but it cannot be denied that there are still many election violations both criminal, administrative and ethical 
in nature, but in practice there are still many recommendations from the Election Supervisory Body that are not implemented by the General Election Commission. The purpose of this paper is to find the use of crime as a last resort in the process of election violations. Normative juridical methods. Ultimium Remedium, the use of crime as a last resort in the process of law enforcement, is very important in the democratic process in Indonesia, because the criminal law is used to guard the spirit of the law.

\section{Keywords: Application, Ultimium Remedium, Election}

\section{Pendahuluan}

Demokrasi secara sederhana dapat dimaknai sebagai 'pemerintahan dari rakyat, oleh rakyat, dan untuk rakyat'. Namun, untuk mewujudkan makna tersebut tidaklah mudah karena demokrasi memerlukan proses panjang dan tahapan-tahapan penting yang harus dilalui, seperti proses konsolidasi demokrasi. ${ }^{1}$ Banyak Negara menciptakan aturan pelanggaran Pemilu dalam mereka. Dalam kaitan dengan itu dikemukan bahwa setiap ketentuan pidana yang dibentuk untuk keperluan hukum harus merefleksikan tujuan penyusunan undang-undang. Dalam kaitan Pemilu, misalnya, Undang-Undang Pemilu bertujuan agar tersedia: "setiap upaya tindakan pencegahan pelanggaran, praktik korupsi, dan praktik-praktik ilegal di Pemilu; dan aturan tentang gugatan Pemilu". ${ }^{2}$

Ciri sebuah negara demokratis adalah seberapa besar negara melibatkan masyarakat dalam perencanaan maupun pelaksanaan pemilihan umum. Sebab partisipasi politik masyarakat (pemilih) merupakan aspek penting dalam sebuah tatanan negara demokrasi. Dalam hubungannya dengan demokrasi, partisipasi politik berpengaruh terhadap legitimasi oleh masyarakat terhadap jalannya suatu pemerintahan. Dalam Pemilu misalnya partisipasi politik berpengaruh terhadap legitimasi masyarakat kepada calon atau pasangan calon yangterpilih. Setiap masyarakat memiliki preferensi dan kepentingan masing-masing

\footnotetext{
${ }^{1}$ R Siti Zuhro, (2019), Demokrasi dan Pemilu Presiden 2019. Jurnal Penelitian Politik, 16 (1), $69-$ 81. DOI: https://doi.org/10.14203/jpp.v16i1.782, hal 69

${ }^{2}$ Dahlan Sinaga, Tindak Pidana Pemilu, Jakarta: Nusamedia, 2018 hal 59
}

DOI: https://doi.org/10.30598/belovol6issue2page157-178 
untukmenentukan pilihan mereka dalam pemilu. Bisa dikatakan bahwa masa depan pejabat publik yang terpilih dalam suatu Pemilu tergantung pada preferensi masyarakat sebagai pemilih. Tidakhanya itu, partisipasi politik masyarakat dalam Pemilu dapat dipandang sebagai evaluasi dan kontrolmasyarakat terhadap pemimpin atau pemerintahan. ${ }^{3}$

Dikemukakan pula, bahwa dalam rangka penegakan demokrasi, upaya perlindungan integritas Pemiku sangat penting. Oleh karenanya, pembuat undang-undang harus mengatur beberapa praktik curang atau pelanggaran pidana Pemilu. Dalam keterkaitannya dengan peraturan pemilu, Undang-Undang tidak hanya mengatur proses Pemilu, tetapi mereka juga melarang perlakuan yang dapat menghabat esensi Pemilu yang bebas dan adil.

Berdasarkan deskripsi tersebut di atas, kemudian dikemukakan bahwa maksud penyusunan peraturan pelanggaran Pemilu tidak hanya melindungi peserta Pemilu (partai politik atau kandidat), tetapi juga lembaga pelaksana dan pemilih. Ketentuan tentang pelanggaran Pemilu ditujukan untuk melindungi proses Pemilu dari segala bentuk pelanggaran. Perlindungan ini akan meningkatkan kualitas pelayanan yang ditujukan oleh perwakilan terpilih atau pemerintah daerah dalam mempresentasikan aspirasi pemilih.

Mengingat pentingnya posisi pemilihan umum bagi sebuah Negara yang demokrasi, maka adalah tidak berlebihan bila dikatakan, kejujuran dan keadilan dalam pelaksanaan pemilihan umum akan mencerminkan kualitas demokrasi di Negara bersangkutan. Kemampuan menampakkan atau mewujudkan pemilihan umum yang jujur dan adil akan berarti pula melihatkan kematangan masyarakat selaku peserta pemilihan umum dalam berdemokrasi. Secara konseptual dan empirik, demokrasi akan tmbuh dan berkembang secara optimal manakala didukukng oleh peradaban masyarakat Negara setempat yang membuka ruang terbentuknya proses demokrasi, peradaban masyaraat dapat bersumber dari bawaan manusia hasil interaksi dengan lingkungan, juga merupakan hasil pelaksanaan program modernisasi yang dilakukan oleh pemerintah dalam berbagai aspek kehidupan melalui pembentukan perangkat aturan tetang pelaksanaan demokrasi.

${ }^{3}$ Daud M. Liando, (2016), PEMILU DAN PARTISIPASI POLITIK MASYARAKAT (Studi Pada Pemilihan Anggota Legislatif Dan Pemilihan Presiden Dan Calon Wakil Presiden Di Kabupaten Minahasa Tahun 2014), Jurnal LPPM Bidang EkoSosBudKum, 3 (2), 14-28, hal 15

DOI: https://doi.org/10.30598/belovol6issue2page157-178 Copyright (c) 2021 Author 
Pada tanggal 6 Agustus 2018 Pelapor JP melakukan pelaporan terhadap Komisi Pemilihan Kota Ambon, atas dugaan pelanggaran administrasi pada tahapan pencalonan, saudara JP merasa telah mengalami kerugian karena namanya tidak ada dalam Daftar Calon Sementara (DCS), dalam hasil kajiannya melalui Putusan 01/ADM/BWSL AMBON/PEMILU/VIII/2018, mengatakan dalam amar putusan :

1. Menyatakan terlapor yaitu KPU Kota Ambon, terbukti secara sah dan meyakinkan melakukan perbuatan Pelanggaran Administrasi Pemilihan Umum Tahun 2019;

2. Memerintahkan kepada KPU Kota Ambon untuk melakukan perbaikan administrasi terhadap tata cara, prosedur, atau mekanisme pada sub tahapan perbaikan daftar calon dan syarat calon serta mengembalikan nama-nama yaitu : a. JP, ke dalam Model B. 1 DPRD Kota Perbaikan Bakal Calon Anggota DPRD Kota Ambon dari Partai Golkar Dapil I Kota Ambon, b. PCIR ke dalam Model B. 1 DPRD Kota Perbaikan Daftar Bakal Calon Anggota DPRD Kota Ambon dari Partai Golkar Dapil III Kota Ambon, c. RL ke Dalam Model B. 1 DPRD Kota Ambon, selanjutnya dilakukan verifikasi syarat calon berdasarkan ketentuan perundang-undangan Pemilu.

3. Memerintahkan KPU Kota Ambon untuk melaksanakan Putusan ini paling lambat 3 (tiga) hari kerja sejak Putusan dibacakan.

Dalam Pasal 251 ayat (3) dan 518 Undang-undang Nomor 7 Tahun 2017 tentang Pemilu mengatakan bahwa :

Pasal 251 ayat 3

KPU, KPU Provinsi, dan KPU Kabupaten/Kota wajib menindaklanjuti temuan dan hasil kajian Bawaslu, Bawaslu Provinsi, dan Bawaslu Kabupaten/Kota sebagaimana dimaksud pada ayat (2).

Pasal 518

Setiap anggota KPU, KPU Provinsi, dan/atau KPU Kabupaten/Kota yang tidak DOI: https://doi.org/10.30598/belovol6issue2page157-178 Copyright (c) 2021 Author 
menindaklanjuti temuan Bawaslu, Bawaslu Provinsi, dan atau Bawaslu Kabupaten/Kota dalam pelaksanaan verifikasi partai politik calon Peserta Pemilu sebagaimana dimaksud dalam Pasal 180 ayat (3) dan/atau pelaksanaan verifikasi kelengkapan administrasi bakal calon anggota DPR, DPD, DPRD provinsi, dan DPRD kabupaten/kota sebagaimana dimaksud dalam Pasal 251 ayat (3) dan Pasal 261 ayat (3) dan/atau pelaksanaan veriflkasi kelengkapan administrasi bakal calon Presiden dan Wakil Presiden dipidana dengan pidana penjara paling lama 3 (tiga) tahun dan denda paling banyak Rp 36.000.000,00 (tiga puluh enam juta rupiah).

\section{Pembahasan}

\section{Penerapan Asas Ultimium Remedium Dalam Tindak Pidana Pemilu}

Perkataan ultimum remedium ini pertama kali dipergunakan oleh Menteri Kehakiman Belanda yaitu Modderman dalam menjawab pertanyaan Mackay seorang parlemen Belanda mengenai dasar hukum perlunya suatu penjatuhan hukuman bagi seseorang yang telah melakukan suatu pelanggaran hukum. Atas pertanyaan tersebut Modderman. menyatakan: "bahwa yang dapat dihukum itu pertama-tama adalah pelanggaran-pelanggaran hukum. Ini merupakan suatu condition sine qua non (syarat yang tidak boleh tidak ada). Kedua, yang dapat dihukum itu adalah pelanggaranpelanggaran hukum yang menurut pengalaman tidaklah dapat ditiadakan dengan cara-cara lain. Hukuman itu hendaknya merupakan suatu upaya terakhir (ultimum remedium). Memang terhadap setiap ancaman pidana ada keberatannya. Setiap orang yang berpikiran sehat akan mengerti hal tersebut tanpa penjelasan lebih lanjut. Ini tidak berarti bahwa ancaman pidana akan ditiadakan, tetapi selalu harus mempertimbangkan keuntungan dan kerugian ancaman pidana benar-benar menjadi upaya penyembuh serta harus menjaga jangan sampai membuat penyakitnya menjadi lebih parah. ${ }^{4}$

\footnotetext{
${ }^{4}$ Machmud, S. Problematika penerapan delik normal dalam perspektif penegakan hukum pidana lingkungan di Indonesia, fungsionalisasi asas ultimum remedium sebagai pengganti asas subsidiaritas. Bandung: CV Mandar Maju. 2012, hal 264
} 
Hamzah sependapat dengan pendapat yang menyatakan bahwa tidak semua masalah rumit di dalam masyarakat kita ini harus diserahkan kepada hukum pidana untuk memecahkannya. Biarkanlah bidang hukum lain yang memecahkan lebih dahulu (ultimum remedium), jika hukum pidana hanya dilihat sebagai hukum sanksi istimewa yaitu sanksi pidana penjara saja (karena hukum pidana bukan hanya penjara saja). Sebagai hukum yang tidak mempunyai norma sendiri, yang normanya sudah diatur oleh bidang hukum lain, seperti perdata, dan lain sebagainya. ${ }^{5}$ Van de Bunt mengemukakan bahwa hukum pidana sebagai ultimum remedium memiliki tiga makna, yaitu:

a. Penerapan hukum pidana hanya terhadap orang yang melanggar hukum secara etis sangat berat;

b. Hukum pidana sebagai ultimum remedium karena sanksi hukum pidana lebih berat dan lebih keras daripada sanksi bidang hukum lain, bahkan sering membawa dampak sampingan, maka hendaknya diterapkan jika sanksi bidang hukum lain tidak mampu menyelesaikan masalah pelanggaran hukum (obat terakhir);

c. Hukum pidana sebagai ultimum remedium karena pejabat administrasilah yang lebih dulu mengetahui terjadinya pelanggaran. Jadi merekalah yang diprioritaskan untuk mengambil langkah-langkah dan tindakan daripada penegak hukum pidana.

Sementara itu Bemmelen sependapat dengan Enshede yang mengemukakan bahwa pidana dan proses pidana itu sendiri hanya sebagai kekecualian untuk menutup kerugian yang terjadi. Dalil remedium harus dipandang tidak semata-mata sebagai sarana untuk perbaikan pelanggaran hukum yang dilakukan atau sebagai pengganti kerugian, akan tetapi sebagai sarana menenangkan kerusuhan yang timbul dalam

\footnotetext{
${ }^{5}$ Elrick, M. Kapita selekta hukum, mengenang Almarhum Prof.H. Oemar Seno Adji, SH. Bandung: Ghalia Indonesia. 1995. hal, 223
} 
masyarakat, karena jika pelanggaran hukum dibiarkan saja akan terjadi tindakan sewenang-wenang. Oleh karena itu, penggunaan hukum pidana harus dijadikan sarana terakhir (ultimum remedium) dan harus dibatasi penggunaannya.

Dalam Undang-Undang Nomor 7 Tahun 2017 ada beberapa pasal yang mengatur soal ancaman pidana di akhir pada proses admistrasi yang tidak dilaksanakan oleh KPU pada tahapan pemilu yaitu : ${ }^{6}$

Pasal 501

Setiap anggota KPPS yang dengan sengaja tidak melaksanakan keputusan KPU Kabupaten/Kota untuk pemungutan suara ulang di TPS dipidana dengan pidana kurungan paling lama 1 (satu) tahun dan denda paling banyak Rp12.000.000,00 (dua belas juta rupiah).

Pasal 502

Ketua dan anggota KPPS yang dengan sengaja tidak melaksanakan ketetapan KPU Kabupaten/Kota untuk melaksanakan pemungutan suara ulang di TPS, dipidana dengan pidana penjara paling lama 1 (satu) tahun dan denda paling banyak Rp12.000.000,00 (dua belas juta rupiah).

Pasal 507

1. Setiap Panwaslu Kelurahan/Desa yang tidak mengawasi penyerahan kotak suara tersegel dari PPS kepada PPK dan tidak melaporkan kepada Panwaslu Kecamatan sebagaimana dimaksud dalam Pasal 390 ayat (6) dipidana dengan pidana kurungan paling lama 1 (satu) tahun dan denda paling banyak Rp12.000.000,00 (dua belasjuta rupiah).

2. Setiap Panwaslu Kecamatan yang tidak mengawasi penyerahan kotak suara tersegel dari PPK kepada KPU Kabupaten/Kota dan tidak melaporkan kepada Bawaslu Kabupaten/Kota sebagaimana dimaksud dalam Pasal 390 ayat (7) dipidana dengan pidana kurungan paling lama 1 (satu) tahun dan denda paling banyak Rp12.000.000,00 (dua belas juta rupiah).

${ }^{6}$ Sarkol, T. (2020). Strategi Pengawasan Pelanggaran Pidana Pemilu Pada Daerah Kepulauan Maluku. JURNAL BELO, 6(1), 32-47. https://doi.org/10.30598/belovol6issue1page32-47, hal 34 
Pasal 508

Setiap anggota PPS yang tidak mengumumkan salinan sertifikat hasil penghitungan suara dari seluruh TPS di wilayah kerjanya sebagaimana dimaksud dalam Pasal 391, dipidana dengan pidana kurungan paling lama 1 (satu) tahun dan denda paling banyak Rp12.000.000,00 (dua belas juta rupiah).

Pasal 512

Setiap anggota KPU, KPU Provinsi, KPU Kabupaten/Kota, PPK, PPS, dan/atau PPLN yang tidak menindaklanjuti temuan Bawaslu, Bawaslu Provinsi, Bawaslu Kabupaten/Kota, Panwaslu Kecamatan, Panwaslu Kelurahan/Desa, dan/atau Panwaslu LN dalam melakukan pemutakhiran data Pemilih, penyusunan dan pengumuman daftar pemilih sementara, perbaikan dan pengumuman daftar pemilih sementara hasil perbaikan, penetapan dan pengumuman daftar pemilih tetap, daftar pemilih tambahan, daftar pemilih khusus, dan/atau rekapitulasi daftar pemilih tetap yang merugikan Warga Negara Indonesia yang memiliki hak pilih sebagaimana dimaksud dalam Pasal 220 ayat (2), dipidana dengan pidana penjara paling lama 3 (tiga) tahun dan denda paling banyak Rp36.000.000,00 (tiga puluh enam juta rupiah).

Pasal 513

Setiap anggota KPU Kabupaten/Kota yang sengaja tidak memberikan salinan daftar pemilih tetap kepada Partai Politik Peserta Pemilu sebagaimana dimaksud dalam Pasal 208 ayat (5) dipidana dengan pidana penjara paling lama 2 (dua) tahun dan denda paling banyak Rp24.000.000,00 (dua puluh empat juta rupiah).

\section{Pasal 518}

Setiap anggota KPU, KPU Provinsi, dan/atau KPU Kabupaten/Kota yang tidak menindaklanjuti temuan Bawaslu, Bawaslu Provinsi, dan/atau Bawaslu Kabupaten/Kota dalam pelaksanaan verifikasi partai politik calon Peserta Pemilu sebagaimana dimaksud dalam Pasal 180 ayat (3) dan/atau pelaksanaan verifikasi kelengkapan administrasi bakal calon anggota DPR, DPD, DPRD provinsi, dan DPRD kabupaten/kota sebagaimana dimaksud dalam Pasal 251 ayat (3) dan Pasal 261 ayat (3) dan/atau pelaksanaan veriflkasi kelengkapan administrasi bakal calon Presiden dan Wakil Presiden dipidana dengan pidana penjara paling lama 3 (tiga) tahun dan denda paling banyak Rp36.000.000,00 (tiga puluh enam juta rupiah). 
Pasal 525 ayat 2

Setiap Peserta Pemilu yang menggunakan kelebihan sumbangan, tidak melaporkan kelebihan sumbangan kepada KPU, dan/atau tidak menyerahkan kelebihan sumbangan kepada kas negara paling lambat 14 (empat belas) hari setelah masa Kampanye Pemilu berakhir dipidana dengan pidana penjara paling lama 2 (dua) tahun dan denda paling banyak Rp500.000.000,00 (lima ratus juta rupiah).

Pasal 528

1. Peserta Pemilu yang menerima sumbangan sebagaimana dimaksud dalam Pasal 339 ayat (2) dan tidak melaporkan kepada KPU dan/atau tidak menyetorkan ke kas negara, dipidana dengan pidana penjara paling lama 4 (empat) tahun dan denda sebanyak 3 (tiga) kali dari jumlah sumbangan yang diterima.

2. Pelaksana dan tim kampanye yang menggunakan dana dari sumbangan yang dilarang dan/atau tidak melaporkan dan/atau tidak menyetorkan ke kas negara sesuai batas waktu yang ditentukan sebagaimana dimaksud dalam Pasal 339 ayat (2), dipidana dengan pidana penjara paling lama 2 (dua) tahun dan denda sebanyak 3 (tiga) kali dari jumlah sumbangan yang diterima.

\section{Pasal 541}

Setiap anggota KPU, KPU Provinsi, dan/atau KPU Kabupaten/Kota yang tidak melaksanakan putusan pengadilan terhadap kasus tindak pidana Pemilu sebagaimana dimaksud dalam Pasal 484 ayat (2) yang telah memperoleh kekuatan hukum tetap, dipidana dengan pidana penjara paling lama 2 (dua) tahun dan denda paling banyak Rp24.000.000,00 (dua puluh empat juta rupiah).

Pasal 543

Setiap anggota Bawaslu, Bawaslu Provinsi, Bawaslu Kabupaten/Kota, Panwaslu Kecamatan, dan/atau Panwaslu Kelurahan/Desa/Panwaslu LN/Pengawas TPS yang dengan sengaja tidak menindaklanjuti temuan dan/atau laporan pelanggaran Pemilu yang dilakukan oleh anggota KPU, KPU Provinsi, KPU Kabupaten/Kota, PPK, PPS/PPLN, dan/atau KPPS/KPPSLN dalam setiap tahapan Penyelenggaraan Pemilu dipidana dengan pidana penjara paling lama 2 (dua) tahun dan denda paling banyak Rp24.000.000,00 (dua puluh empat juta rupiah). 
Dari pasal-pasal diatas yang mengancam pidana dalam proses maladministratf. Ada pasal yang spesifik menganut ajaran ultimium remedium adalah

Pasal 501

Setiap anggota KPPS yang dengan sengaja tidak melaksanakan keputusan KPU Kabupaten/Kota untuk pemungutan suara ulang di TPS dipidana dengan pidana kurungan paling lama 1 (satu) tahun dan denda paling banyak Rp12.000.000,00 (dua belas juta rupiah).

Dalam pasal 501 ini ada laporan dari masyarakat kepada Bawaslu, dan sudah ada putusan administratif, yang menetapkan bahwa benar telah terjadi pelanggaran admistratif di TPS A, Keputusan Bawaslu diteruskan ke KPU untuk ditindak lanjuti, namun ketika KPU menyurati untuk persiapan pemungutan suara ulang Ketua KPPS dan Anggota KPPS tidak mau untuk melakukan proses pemilian ulang, maka pengunaan ancaman pidana dianggap efektif sebagaimana disebutkan dalam Pasal 501.

Pasal 512

Setiap anggota KPU, KPU Provinsi, KPU Kabupaten/Kota, PPK, PPS, dan/atau PPLN yang tidak menindaklanjuti temuan Bawaslu, Bawaslu Provinsi, Bawaslu Kabupaten/Kota, Panwaslu Kecamatan, Panwaslu Kelurahan/Desa, dan/atau Panwaslu LN dalam melakukan pemutakhiran data Pemilih, penyusunan dan pengumuman daftar pemilih sementara, perbaikan dan pengumuman daftar pemilih sementara hasil perbaikan, penetapan dan pengumuman daftar pemilih tetap, daftar pemilih tambahan, daftar pemilih khusus, dan/atau rekapitulasi daftar pemilih tetap yang merugikan Warga Negara Indonesia yang memiliki hak pilih sebagaimana dimaksud dalam Pasal 220 ayat (2), dipidana dengan pidana penjara paling lama 3 (tiga) tahun dan denda paling banyak Rp36.000.000,00 (tiga puluh enam juta rupiah).

Bahwa dalam putusan Bawaslu mengharuskan penyelenggara pemilu dan jajarannya untuk menindaklanjuti temuan Bawaslu, Bawaslu Provinsi, Bawaslu Kabupaten/Kota, Panwaslu Kecamatan, Panwaslu Kelurahan/Desa, dan/atau 
Panwaslu LN dalam melakukan pemutakhiran data Pemilih, penyusunan dan pengumuman daftar pemilih sementara, perbaikan dan pengumuman daftar pemilih sementara hasil perbaikan, penetapan dan pengumuman daftar pemilih tetap, daftar pemilih tambahan, daftar pemilih khusus, dan/atau rekapitulasi daftar pemilih tetap. Maka diterapkan ancaman pidana agar menimbulkan efek jera.

Pasal 541

Setiap anggota KPU, KPU Provinsi, dan/atau KPU Kabupaten/Kota yang tidak melaksanakan putusan pengadilan terhadap kasus tindak pidana Pemilu sebagaimana dimaksud dalam Pasal 484 ayat (2) yang telah memperoleh kekuatan hukum tetap, dipidana dengan pidana penjara paling lama 2 (dua) tahun dan denda paling banyak Rp24.000.000,00 (dua puluh empat juta rupiah).

Dalam pasal ini KPU, KPU Provinsi, dan/atau KPU Kabupaten/Kota wajib menikdak lanjuti putusan pidana pemilu yang dijatukan pengadilan jika tidak maka diberlakukan penjatuhan pidana bagi KPU, KPU Provinsi, dan/atau KPU Kabupaten/Kota yang tidak melakukan putusan tersebut.

Pasal 518

Setiap anggota KPU, KPU Provinsi, dan/atau KPU Kabupaten/Kota yang tidak menindaklanjuti temuan Bawaslu, Bawaslu Provinsi, dan/atau Bawaslu Kabupaten/Kota dalam pelaksanaan verifikasi partai politik calon Peserta Pemilu sebagaimana dimaksud dalam Pasal 180 ayat (3) dan/atau pelaksanaan verifikasi kelengkapan administrasi bakal calon anggota DPR, DPD, DPRD provinsi, dan DPRD kabupaten/kota sebagaimana dimaksud dalam Pasal 251 ayat (3) dan Pasal 261 ayat (3) dan/atau pelaksanaan veriflkasi kelengkapan administrasi bakal calon Presiden dan Wakil Presiden dipidana dengan pidana penjara paling lama 3 (tiga) tahun dan denda paling banyak Rp36.000.000,00 (tiga puluh enam juta rupiah).

Jika sudah ada putusan Bawaslu Bawaslu Provinsi, dan/atau Bawaslu Kabupaten/Kota dalam pelaksanaan verifikasi partai politik calon Peserta 
Pemilu, maka KPU, KPU Provinsi, dan/atau KPU Kabupaten/Kota wajib menindaklanjuti jika tidak maka akan dikenakan ancaman pidana.

\section{Pasal 543}

Setiap anggota Bawaslu, Bawaslu Provinsi, Bawaslu Kabupaten/Kota, Panwaslu Kecamatan, dan/atau Panwaslu Kelurahan/Desa/Panwaslu LN/Pengawas TPS yang dengan sengaja tidak menindaklanjuti temuan dan/atau laporan pelanggaran Pemilu yang dilakukan oleh anggota KPU, KPU Provinsi, KPU Kabupaten/Kota, PPK, PPS/PPLN, dan/atau KPPS/KPPSLN dalam setiap tahapan Penyelenggaraan Pemilu dipidana dengan pidana penjara paling lama 2 (dua) tahun dan denda paling banyak Rp24.000.000,00 (dua puluh empat juta rupiah).

Bila ada dugaan pelanggaran adminstrasi atau pelanggaran pidana baik yang dilaporkan maupun yang ditemukan Bawaslu, Bawaslu Provinsi, Bawaslu Kabupaten/Kota, Panwaslu Kecamatan, dan/atau Panwaslu Kelurahan/Desa/Panwaslu LN/Pengawas TPS, wajib ditindak lanjuti, jika tidak maka ancamannya adalah pidana.

\section{Kasus Posisi Perkara Pelanggaran Adminsitrasi Pemilu Yang Dapat Diterapkan Pidana.}

Berikut ini kronologis kejian mulai dari awal proses pelanggaran pemilu sampai pada putusan Bawaslu Kota Ambon dan Putusan Dewan Komisi Kode Etik Pemilu.

a. Bahwa pada tanggal 13 Juli 2018 DPD II Partai Golkar Kota Ambon dalam hal ini Tim 13 (Tim Penjaringan Sebagaimana Petunjuk Pelaksanaan Nomor 11/DPP/GOLKAR/V/2018) mengusulkan nama-nama bakal calon berjumlah $120 \%$ dari jumlah kursi di setiap Dapil kepada Pengurus DPD Partai Golkar Provinsi Maluku untuk diputuskan, kemudian pada tanggal 16 Juli 2018 DPD I Partai Golkar Provinsi Maluku menyetujui dan menetapkan nama-nama Bakal Calon Anggota DPRD Kota Ambon dengan SK Nomor : 
KEP-19/DPD/GOLKAR-MAL/VII/2018 tentang perubahan Nama Pada Daftar Calon Anggota DPRD Kota Ambon Pada Pemilihan Umum Tahun 2019 Dari Partai Golkar;

b. Bahwa KPU Kota Ambon telah menerima Pendaftaran atau pergantian Bakal Calon Legislatif Partai Golkar Kota Ambon atas nama Joga Papilaya, S, SOS, Claudio Patrick Rahakbauw, dan Roni Latumeten;

c. Bahwa kemudian pada tanggal 17 Juli 2018, sesuai dengan pentahapan, jadwal dan program sebagaimana diatur dalam PKPU Nomor 7 Tahun 2017 tentang Tahapan, Program dan Jadwal Penyelenggaraan Legislatif 2019 DPD II Partai Golkar Kota Ambon telah mendaftarkan Bakal Calon Anggota Legislatif partai Golkar Kota Ambon ke KPU Kota Ambon dimana Pengadu juga merupakan salah satu Bakal Calon dari Dapil Ambon 1 dengan Nomor Urut 3 yang di daftarkan;

d. Bahwa Bakal Calon Anggota Legislatif Partai Golkar telah melalui proses seleksi yang demokratis dan terbuka untuk umum sesuai dengan AD/ART atau aturan internal Partai Golkar, hal mana dibuktikan dengan Surat Pernyataan dari Pimpinan Partai Politik yang dimasukan pada saat pendaftaran pada tanggal 17 Juli 2018 tersebut;

e. Bahwa pada saat pendaftaran/pengajuan Bakal Calon Anggota legislatif (anggota DPRD Kota Ambon) Partai Golkar dengan sengaja tidak menyerahkan kelengkapan syarat calon dari Bakal Calon Anggota Legislatif DPRD Kota Ambon tahun 2019. Hal ini sebagaimana terungkap dalam instrument verifikasi kelengkapan dan keabsahan dokumen bakal calon;

f. Bahwa pada tanggal 28 Juli 2018, DPD II Partai Golkar Kota Ambon menyampaikan Surat Nomor R-42/DPD-PG/KA/VII/2018 perihal penerbitan SK baru kepada DPD Partai Golkar Provinsai Maluku dan dalam lampiran surat tersebut, nama Pengadu (Joga Papilaya, S. SOS), Roni 
Latumeten dan Claudio Patrick Rahakbauw sudah dihilangkan dan diganti dengan orang lain;

g. Bahwa pada tanggal 30 Juli 2018, DPD 1 Partai Golkar Provinsi Maluku melalui Suratnya Nomor B-52/DPD/GOLKAR-MAL/VII/MAL secara tegas menyatakan bahwa tetap pada Surat keputusannya yang semula yaitu SK Nomor KEP-19/DPD/GOLKAR-MAL/VII/2018;

h. Bahwa dalam tahapan pendaftaran /pengajuan Bakal Calon Anggota DPRD Kota Ambon, atas nama Joga Papilaya, S.Sos telah menyerahkan kelengkapan administrasi Bakal Calon Anggota DPRD Kota Ambon kepada DPD II Partai Golkar Kota Ambon yang dibuktikan dengan checklist tertanggal 11 Juli 2018 yang menyatakan syarat calon yang bersangkutan telah lengkap, akan tetapi pada saat pendaftaran/pengajuan Bakal Calon Anggota DPRD Kota Ambon tanggal 17 Juli 2018, DPD II Partai Golkar Kota Ambon tidak menyerahkan kelengkapan administrasi bakal calon tetapi hanya membawa BB. 1 dan BB. 2 untuk diserahkan kepada KPU Kota Ambon;

i. Bahwa pada tahapan perbaikan, DPD II Partai Golkar Kota Ambon melakukan pergantian 3 (tiga) orang bakal calon anggota DPRD Kota Ambon atas nama Joga Papilaya dalam hal ini sebagai pelapor beserta 2 (dua) orang rekan atas nama Claudio Patrick Imanuel Rahakbauw dan Rony Latumeten, yang dilakukan oleh DPD II Partai Golkar Kota Ambon tidak secara demokratis dan terbuka;

j. Bahwa KPU Kota Ambon pada tahapan perbaikan tetap menerima berkas pergantian dari DPD II Partai Golkar Kota Ambon yang tidak dilakukan secara demokratis dan terbuka sesuai dengan pasal 11 dan pasal 12 PKPU Nomor 20 Tahun 2018 serta AD/ART dan aturan internal Partai Golkar;

k. Bahwa korban melakukan pelaporan pada Baswalu Kota Ambon, dari hasil penyelesaian Pelanggaran Administratif Pemilihan Umum yang dilakukan 
oleh Bawaslu Kota Ambon, yang termuat dalam Putusan Bawaslu Kota Ambon Nomor 01/ADM/BWSL.AMBON/PEMILU/VIII/2018.

1. Bahwa amar putusan Bawaslu Kota Ambon Nomor 01/ADM/BWSL.AMBON/PEMILU/VIII/2018, menyebutkan :

Pertama, Menyatakan Terlapor yaitu KPU Kota Ambon, terbukti secara sah dan meyakinkan melakukan perbuatan Pelanggaran Administrasi Pemilihan Umum tahun 2019.

Kedua, Memerintahkan kepada KPU Kota Ambon untuk melakukan perbaikan administrasi terhadap tata cara, prosedur, atau mekanisme pada sub tahapan perbaikan daftar calon dan syarat calon serta mengembalikan nama-nama yaitu; 1) Joga Papilaya, S. Sos, ke dalam model B.1 DPRD Kota Perbaikan Daftar Bakal Calon Anggota DPRD Kota Ambon dari Partai Golkar Dapil II Kota Ambon, 2) Patrick Claudio Imanuel Rahakbauw ke dalam model B.1 DPRD Kota Perbaikan Daftar Bakal Calon Anggota DPRD Kota Ambon dari Partai Golkar Dapil III Kota Ambon dan 3) Rony Latumeten ke dalam model B.1 DPRD Kota Perbaikan Daftar Bakal Calon Anggota DPRD Kota Ambon dari Partai Golkar Dapil III Kota Ambon, selanjutnya dilakukan verivikasi syarat calon berdasarkan ketentuan perundan-undangan Pemilu;

Ketiga, Memerintahkan KPU Kota Ambon untuk melaksanakan putusan ini paling lambat 3 (tiga) hari kerja sejak putusan dibacakan.

m. Bahwa setelah Bawaslu Kota Ambon memutuskan Sengketa Administrasi yang dimohonkan oleh Pengadu sebagaimana termuat dalam putusan sebagaimana disebutkan diatas, KPU Kota Ambon sampai pada saat Penetapan Daftar Calon Tetap Anggota DPRD Kota Ambon Tahun 2018 sebagaimana tertuang dalam Surat Keputusan Nomor 25/HK.031.I.KEP/8171/KPU-KOT/IX/2018 Tentang Penetapan Daftar 
Calon Tetap Anggota DPRD Kota Ambon Pada Pemilu 2019 secara sengaja dan terang-terangan tidak melakasanakan putusan bawaslu a quo.

n. Bahwa DKKP mengeluarkan Putusan Nomor 260/DKPP-PKE-VII/2018 Dewan Kehormatan Penyelenggara Pemilihan Umum Republik Indonesia yang amar putusannya memutuskan :

Pertama, Mengabulkan pengaduan Pengadu untuk sebagian;

Kedua, Menjatuhkan sanksi berupa Peringatan kepada Teradu I M K selaku Ketua merangkap Anggota, Teradu II K T, Teradu III M.S F, Teradu IV S B. L, dan Teradu V R M.B U masing-masing sebagai Anggota KPU Kota Ambon sejak dibacakannya Putusan ini;

Ketiga, Memerintahkan Komisi Pemilihan Umum Provinsi Maluku untuk menindaklanjuti Putusan ini paling lama 7 (tujuh) hari sejak dibacakan;

Keempat, Memerintahkan Badan Pengawas Pemilihan Umum Republik Indonesia untuk mengawasi pelaksanaan Putusan ini.

\section{Analisis Kasus.}

Bangsa Indonesia baru saja melalui penyelenggaraan Pemilu tahun 2019 yang merupakan siklus pemilu kelima sejak bergulirnya era reformasi. Di samping 5 kali pemilu legislatif dan Presiden, tidak terhitung jumlah pemilihan kepala daerah yang dilakukan secara langsung sejak tahun 1999. Pemilu di era reformasi ini juga mencatatkan penyelenggaraan pemilu presiden dan wakil presiden secara langsung pada tahun 2004 dari yang sebelumnya kepala eksekutif ini dipilih melalui sistem perwakilan oleh MPR, serta pemilihan Kepala Daerah secara langsung pada tahun 2004 dari yang sebelumnya dipilih melalui sistem perwakilan oleh DPRD.

Genap dua dekade penyelenggaraan pemilu paska rezim Orde Baru ini, tercatat beberapa kali perubahan maupun penggantian kerangka hukum/peraturan perundangundangan yang mengatur tentang pemilu maupun pemilihan kepala daerah, untuk 
mengubah dan memperbaiki beberapa aspek pengaturan antara lain terkait kelembagaan penyelenggara pemilu, metode pencalonan, metode konversi suara menjadi kursi, maupun jenis jabatan yang dipilih melalui Pemilu. Aspek kelembagaan penyelenggara pemilu dan metode konversi suara menjadi kursi menjadi bagian yang paling sering diubah dalam beberapa kali revisi Undang-Undang Pemilu.

Pemilu merupakan praktek perwujudan hak asasi manusia. Pengejawantahan penyelenggaraan pemilu yang demokratis menjadi salah satu bagian dari upaya membentuk pemerintahan yang mampu menjamin perlindungan terhadap hak asasi, rule of law, dan pembentukan institusi yang demokratis. Esensi Pemilu adalah proses kompetisi politik untuk memperebutkan dukungan para pemilik kedaulatan (rakyat) agar mereka mau mewakilkan mandate kedaulatannya, sehingga dapat menjadi legitimasi kepada pemenang pemilu untuk menjalankan kekuasaan politik kenegaraan. Sebagai sebuah kompetisi (apalagi kompetisi politik), proses ini sangat rawan dan rentan terhadap praktek pelanggaran, baik dalam bentuk kesengajaan maupun ketidaksengajaan. Baik lembaga penyelenggara pemilu, peserta pemilu dan masyarakat itu sendiri.

Badan penyelenggara pemilu harus dijamin bisa bekerja independen. Hal ini merupakan persoalan penting karena mesin-mesin pelaksana pemilu membuat dan melaksanakan keputusan yang dapat mempengaruhi hasil pemilu. Oleh karena itu, badan tersebut harus bekerja dalam kerangka waktu yang cukup, memiliki sumberdaya yang mumpuni, dan tersedia dana yang memadai. Kerangka hukum pemilu harus mengatur ukuran, komposisi, dan masa kerja anggota badan pelaksana pemilu. Juga perlu diatur hubungan antara badan pelaksana pemilu pusat dan badan-badan pemilu tingkat yang lebih rendah serta hubungan antara semua badan pemilu dengan badan eksekutif. Kerangka hukum harus membuat ketentuan tentang mekanisme untuk memproses, memutuskan, dan menangani keluhan dalam pemilu secara tepat waktu.

Dalam Undang-Undang Nomor 7 Tahun 2017 tentang Pemihan Umum, ada beberapa alternatif penyelesaan masalah hukum yang dihadapi, mulai dari penyelesaian di tingkat Bawaslu sampai masuk pada rana hukum pidana, dan masuk 
dalam rana kode etik yang berbicara tentang etika penyelengga pemilu. Ada beberapa analisa hukum yang dibahas oleh penulis berdasarkan kasus posisi yang telah dijelaskan di atas yaitu : ${ }^{7}$

a. Bahwa pelapor melaporkan dugaan tindakan pelanggaran administrasi yang dilakukan oleh Komisi Pemilihan Umum Kota Ambon (KPU Kota Ambon), kepada Badan Pengawas Pemilu Kota Ambon (Bawaslu Kota Ambon).;

b. Bahwa Bawaslu Kota Ambon telah melaksanakan tugas untuk melakukan penindakan dalam hal menerima dan menindaklanjuti laporan yang berkaitan dengan dugaan pelanggaran administratif Pemilu sebagaimana diatur dalam Pasal 102 Ayat (2) huruf d Undang-undang Nomor 7 Tahun 2017 Tentang Pemilihan Umum;

c. Bahwa Bawaslu Kota Ambon mempunyai wewenang untuk menerima, memeriksa, mengkaji, dan memutus dugaan pelanggaran administratif pemilu sebagaimana telah diatur dalam Pasal 4 Ayat (1) Peraturan Badan Pengawas Pemilihan Umum Nomor 8 Tahun 2018 Tentang Penyelesaian Pelanggaran Administratif Pemilihan Umum, yang objek pelanggarannya berupa perbuatan atau tindakan yang melanggar tata cara, prosedur, atau mekanisme yang berkaitan dengan administrasi pelaksanaan Pemilu dalam setiap tahapan Penyelenggaraan Pemilu yang telah diatur dalam Pasal 19 Peraturan Badan Pengawas Pemilihan Umum Nomor 8 Tahun 2018 Tentang Penyelesaian Pelanggaran Administratif Pemilihan Umum;

d. Bahwa Amar Putusan Bawaslu Kota Ambon nomor : 01/ADM/BWSL.AMBON/PEMILU/ VIII/2018, Menyatakan :

Pertama,Terlapor yaitu KPU Kota Ambon, terbukti secara sah dan meyakinkan melakukan perbuatan Pelanggaran Administrasi Pemilihan Umum Tahun 2019;

${ }^{7}$ Patty, J. (2019). jmp Pelarangan Mantan Terpidana Korupsi Menjadi Calon Kepala Daerah Agar Menimbulkan Efek Jera. JURNAL BELO, 5(1), 1-9. https://doi.org/10.30598/belovol5issue1page1-9, hal 7 
Kedua, Memerintahkan kepada KPU Kota Ambon untuk melakukan perbaikan administrasi terhadap tata cara, prosedur, atau mekanisme pada sub tahapan perbaikan daftar calon dan syarat calon serta mengembalikan nama-nama yaitu ; 1) Joga Papilaya, S.Sos, ke dalam Model B.1 DPRD Kota Perbaikan Daftar Bakal Calon Anggota DPRD Kota Ambon dari Partai Golkar Dapil I Kota Ambon, 2) Patrick Claudio Imanuel Rahakbauw ke dalam Model B.1 DPRD Kota Perbaikan Daftar Bakal Calon Anggota DPRD Kota Ambon dari Partai Golkar Dapil III Kota Ambon, dan 3) Rony Latumeten ke dalam Model B.1 DPRD Kota Perbaikan Daftar Bakal Calon Anggota DPRD Kota Ambon dari Partai Golkar Dapil III Kota Ambon, selanjutnya dilakukan verifikasi syarat calon berdasarkan ketentuan perundang-undangan Pemilu;

Ketiga, memerintahkan KPU Kota Ambon untuk melaksanakan Putusan ini paling lambat 3 (tiga) hari kerja sejak Putusan dibacakan.

e. Bahwa berdasarkan Amar Putusan Bawaslu Kota Ambon, telah jelas memerintahkan KPU Kota Ambon untuk segera memproses Putusan tersebut dengan mengembalikan ketiga nama yang tercantum dalam Putusan tersebut dan melakukan verifikasi syarat calon berdasarkan ketentuan perundang-undangan dalam Pemilihan Umum;

f. Bahwa Putusan Bawaslu Kota Ambon nomor: 01/ADM/BWSL.AMBON/PEMILU/ VIII/2018 tertanggal 30 agustus 2018 adalah bersifat mengikat, yang artinya bahwa KPU Kota Ambon wajib untuk menindaklanjuti Putusan dari Bawaslu Kota Ambon;

g. Bahwa terhadap Putusan Bawaslu Kota Ambon, KPU Kota Ambon menyurati KPU RI dengan nomor: 1166/PL.01.4/8171/KPU-KOT/IX/2018, tertanggal 05 september 2018.

h. Bahwa surat KPU kota Ambon Ke KPU RI telah lewat 3 (tiga) hari dari tanggal 30 Agustus 2018, ini berarti KPU Kota Ambon, tidak melaksanakan perintah Putusan Bawaslu Kota Ambon nomor: 01/ADM/BWSL.AMBON/PEMILU/ VIII/2018.

Dalam persidangan di Dewan Komisi Kode Etik Penyelenggara Pemilu, KPU Menyampaikan mendalilkan telah melaksanakan Putusan 
ajudikasi Bawaslu Kota Ambon. Dalam persidangan para Teradu menjawab telah meminta Partai Golkar Kota Ambon menyampaikan Dokumen pihak pengadu agar dapat dilaksanakan mekanisme verifikasi syarat pencalonan sesuai ketentuan peraturan perundang-undangan dalam rangka melaksanakan putusan Bawaslu Kota Ambon. Para Teradu juga menjawab telah mengirim surat kepada pihak Terkait Bawaslu Kota Ambon menanyakan kejelasan makna putusan pada frasa 'mengembalikan nama-nama' terkait amar untuk mengembalikan nama-nama Joga Papilaya, Patrick Claudio Imanuel Rahakbauw dan Rony Latumeten ke dalam model B.1 Perbaikan sebagai Daftar Bakal Calon Anggota DPRD Kota Ambon dari Partai Golkar yang tidak dijawab oleh pihak Terkait karena telah dianggap jelas. Padahal Pasal 251 mengatakan :

(1) Bawaslu, Bawaslu Provinsi, Bawaslu Kabupaten/Kota melakukan pengawasan atas pelaksanaan verifikasi kelengkapan administrasi bakal calon anggota DPR, DPRD provinsi, dan DPRD kabupatenjkota yang dilakukan oleh KPU, KPU Provinsi, dan KPU Kabupaten/Kota.

(2) Dalam hal pengawasan sebagaimana dimaksud pada ayat (1) menemukan unsur kesengajaan atau kelalaian anggota KPU, KPU Provinsi, dan KPU Kabupaten/Kota berakibat merugikan bakal calon anggota DPR, DPRD provinsi, dan DPRD kabupatenjkota, maka Bawaslu, Bawaslu Provinsi, dan Bawaslu KabupatenjKota menyampaikan temuan dan hasil kajian kepada KPU, KPU Provinsi, dan KPU Kabupaten/Kota.

(3) KPU, KPU Provinsi, dan KPU Kabupaten/Kota wajib menindaklanjuti temuan dan hasil kajian Bawaslu, Bawaslu Provinsi, dan Bawaslu Kabupaten/Kota sebagaimana dimaksud pada ayat (2)

Bahwa pasal 518 berisi tentang ancaman pidana

Setiap anggota KPU, KPU Provinsi, dan/atau KPU Kabupaten/Kota yang tidak menindaklanjuti temuan Bawaslu, Bawaslu Provinsi, danjatau Bawaslu Kabupaten/Kota dalam pelaksanaan verifikasi partai politik calon Peserta Pemilu sebagaimana dimaksud dalam Pasal 180 ayat (3) dan/atau pelaksanaan verifikasi kelengkapan administrasi bakal calon anggota DPR, DPD, DPRD 
provinsi, dan DPRD kabupaten/kota sebagaimana dimaksud dalam Pasal 251 ayat (3) dan Pasal 261 ayat (3) dan/atau pelaksanaan veriflkasi kelengkapan administrasi bakal calon Presiden dan Wakil Presiden dipidana dengan pidana penjara paling lama 3 (tiga) tahun dan denda paling banyak Rp36.000.000,00 (tiga puluh enam juta rupiah).

i. Bahwa pasal 518 merupakan penerapan ancaman pidana jika tidak melanjutkan putusan Bawaslu Kota Ambon yang merupakan penerapan asas Utimium Remedium dapat dilihat dalam pasal tersebut;

j. Jadi dalam kasus ini tergambarkan bahwa penjatuhan sanksi pidana untuk menjaga pemilu dapat berjalan secara jujur adil dan berkualitas.

\section{Penutup}

Dalam Undang-Undang Nomor 7 Tahun 2017 tentang Pemilihan Umum, ada beberapa pasal yang merupakan pengunaan pidana sebagai upaya terakhir bila putusan pegadilan atau putusan Badan Pengawas Pemilu tidak dilakukan oleh Komisi Pemilhan umum yaitu ; Pasal 501; Pasal 502; Pasal 507; Pasal 508; Pasal 512; Pasal 513; Pasal 518; Pasal 525 ayat 2; Pasal 528; Pasal 541; Pasal 543. Penerapan pasal-pasal ini merupakan implementas dari asas Ultimium Remedium. Dari pembahasan di atas dapat disimpulkan akibat hukum tidak dilaksanakan Putusan Administrasi Bawaslu Kota Ambon oleh Komisi Pemilihan Umum, adalah Pidana sebagaimana diatur didalam pasal 521 dan pasal 518 Undang-undang Nomor 7 Tahun 2017 tentang Pemilihan Umum. Saran yang diberikan penegakan hukum pemilu jangan saja terpusat pada peserta pemilu, namun juga harus tegas bagi penyelenggara pemilu yang tidak melaksanakan perintah undang-undang dengan alasan yang tidak sah, seperti kasus diatas. Dan pemberian sanksi pidana untuk pasal-pasal putusan adminsitratif yang tidak ditindak lanjuti harus lebih banyak lagi, agar menimbulkan efek jera, dan penyelenggara patuh pada perinta undang-undang. 


\section{Daftar Pustaka}

\section{Jurnal}

[1] Daud M. Liando, (2016), PEMILU DAN PARTISIPASI POLITIK MASYARAKAT (Studi Pada Pemilihan Anggota Legislatif Dan Pemilihan Presiden Dan Calon Wakil Presiden Di Kabupaten Minahasa Tahun 2014), Jurnal LPPM Bidang EkoSosBudKum, 3 (2), 14-28.

[2] Patty, J. (2019). jmp Pelarangan Mantan Terpidana Korupsi Menjadi Calon Kepala Daerah Agar Menimbulkan Efek Jera. JURNAL BELO, 5(1), 1-9. https://doi.org/10.30598/belovol5issuelpage1-9

[3] R Siti Zuhro, (2019), Demokrasi dan Pemilu Presiden 2019. Jurnal Penelitian Politik, 16 (1), 69-81. DOI: https://doi.org/10.14203/jpp.v16i1.782.

[4] Sarkol, T. (2020). Strategi Pengawasan Pelanggaran Pidana Pemilu Pada Daerah Kepulauan Maluku. JURNAL BELO, 6(1), 32-47. DOI :https://doi.org/10.30598/belovol6issue1page32-47

\section{Buku}

[5] Dahlan Sinaga, (2018) Tindak Pidana Pemulu, Jakarta: Nusamedia.

[6] Elrick, M. (1995). Kapita selekta hukum, mengenang Almarhum Prof. H. Oemar Seno Adji, SH. Bandung: Ghalia Indonesia.

[7] Machmud, S. (2012) Problematika penerapan delik normal dalam perspektif penegakan hukum pidana lingkungan di Indonesia, fungsionalisasi asas ultimum remedium sebagai pengganti asas subsidiaritas. Bandung: CV Mandar Maju. 